\title{
In defence of partisan justice - an ethical reflection on "the preferential option for the poor”
}

P J Naude

(Nelson Mandela Metropolitan University)

\section{ABSTRACT}

\section{In defence of partisan justice - an ethical reflection on "the preferential option for the poor"}

Can one defend a form of partisan justice? This question is answered in the affirmative in the light of two broad arguments: The theological argument arises from the preferential option for the poor from Latin America, and the philosophical argument is derived from John Rawls' notion of the least advantaged representative person and assistance due to burdened societies in a global context. In closing, a number of important implications of such a partisan notion of both distributive and cultural justice are explicated.

This article is developed in three sections. The first section briefly sketches a profile of the different theological arguments underlying a preferential option for the poor as particularly developed by Latin American liberation theologians, and later accepted in wider ecumenical circles.

In the second section, philosophical arguments for a position of "prioritarianism" which seems to support such "preferential option" are outlined. This is attempted via a discussion of two influential books by well-known American political philosopher, John Rawls, namely his A theory of justice (1973), and The law of peoples (1999).

Section three concludes the article by demonstrating the synergy between these theological and philosophical views, and by pointing out - in a provisional manner - the important consequences of such a "preferential" or "partisan" view for guiding ethical reflection on local and global socio-economic relations. 


\section{A PROFILE OF THEOLOGICAL ARGUMENTS FOR PARTISAN JUSTICE}

One could construe the following four theological arguments that cumulatively provide a rationale for and are at the same time expressions of the notion of a preferential option for the poor. ${ }^{1}$

\subsection{The methodological argument}

The advent of a cluster of liberation theologies - Latin American, black, African, feminist/womanist, gay/lesbian, and ecological - was accompanied by a specific self-understanding that what is at stake is not just new theological themes on liberation, but the very way of constructing theology as such. Despite the inner complexities of and differences amongst these pluralistic array of liberation theologies, there is a specific methodological convergence: Liberation theologies generally take as methodological point of departure the oppressive experience of those who fall within the focus of that particular theology. These focal points explain in each case who would be seen as "poor, marginalised and oppressed". This includes economically or materially poor people, racially oppressed black people, culturally marginalized or colonised people, middle class women and poor black women, gay and lesbian people, people suffering from HIV/AIDS, as well as the oppression of animals and the non-human world via a narrow anthropocentric construction of reality $^{2}$.

For the purposes of this essay, a very general description of Latin American liberation theology is undertaken ${ }^{3}$. There is a

1 There is a certain circularity involved here: The option for the poor historically precedes the development of Latin American liberation theologies (see below). Therefore these theologies are expressions in different ways of the underlying option; but in turn these "expressions" become arguments for a reinforcement of the option.

2. Literature in each case is too vast to cite here. For a very useful overview of some of these theologies from a South African perspective, see the first part of Initiation into theology, edited by Maimela and König (2001).

$3 \quad$ It must be made clear: One cannot write a few paragraphs on such a vast theology (or theologies) without fairly sweeping generalizations and loss of specifics. It is also impossible to refer to all relevant literature at each point. The value, though, of the "generalist" approach here, is that it serves a heuristic function in the elucidation of a specific focal point. It is for the reader to judge 
twofold motivation for this particular choice: First. The historical origin of the specific terminology, "the preferential option for the poor", lies in Latin American Catholicism. What later became Latin American liberation theology stands the closest to these historical roots. The first indications of the term are already present in Gaudium et Spes, emanating from Vaticanum II (1965). It found its way in more explicit forms into the second general conference of Latin American bishops at Medellin (1968), and was taken up explicitly as a chapter entitled "the preferential option for the poor" in the final document of the third bishops' conference in Puebla, Mexico (1979) ${ }^{4}$.

Second. Although "the option for the poor" has been adopted by other liberation theologies, and later by the ecumenical movement ${ }^{5}$, Latin American liberation theology is, in my view, the best example of a theology constructed specifically around this option as prism through which all theological loci are viewed.

In a short, illuminating passage, Gutierrez (1993:239) explains the preferential option for the poor:

"The very term preference obviously precludes any exclusivity; it simply points to who ought to be first - no the only objects of our solidarity. He points out that Liberation Theology "has insisted on the importance of maintaining both the universality of God's love and the divine predilection for 'history's last"'. What the word option seeks to emphasize "is the free commitment of a decision. The option for the poor is not optional in the sense that a Christian need not necessarily make it, any more than the love we owe every human being, without exception, is not optional. It is a matter of a deep, ongoing solidarity, a voluntary daily involvement with the world of the poor" (Gutierrez 1993:240). The reference to

whether the exposition below contradicts the general thrust of liberation theologies from Latin America.

4 See the discussion of original documents by Gutierrez (1993:239-240), and the more detailed overview and analysis by Bedford-Strohm 1993:151-166.

5 This theological view is, for example, echoed by the ecumenical church in an exposition of the Nicene creed: "In the particular case of human oppression, the victim is assured that God is never on the side of the oppressor, the bringer of death, but will, in justice, protect the rights and lives of the victims" (WCC 1991:63). 
the poor denotes at least three forms of poverty: material poverty (physically poor), social poverty (being marginalised due to racial, cultural or gender oppression), and spiritual poverty (openness to God's will and solidarity with the poor) $(1993: 235-7)^{6}$.

The methodological renewal brought by liberation theology has been formulated by Gustavo Gutierrez in a classical exposition back in 1971. According to him liberation theology "...offers us not so much a new theme for reflection as a new way to do theology" (Gutierrez 1973:15; original emphasis). He thus formulates: "Theology is a critical reflection on Christian praxis in the light of the Word" (Gutierrez 1973:13). The starting point of theological reflection is not revelation or tradition, but "purely and simply, the daily experience of the unjust poverty in which millions of our fellow Latin Americans are obliged to live" (Oliveros 1993: 4). What inform theological reflection at the beginning are the facts and questions derived from the world. And this world is the world of the poor and the marginalized, a reality of social misery. It is the experience of these poor and marginalized people from "the underside of history" that informs theology as liberating process.

There are actually three forms of theologies inherent in "liberation theology" as such. Clodovis Boff names them metaphorically the roots, the trunk, and the branches in the tree of liberation theology. The "roots" are popular liberation theology done by ordinary Christians in base communities in a diffuse and less organised manner with the basic method of confronting life conditions with the message of the gospel. The "trunk" refers to pastoral liberation theology done by church assemblies, (lay) pastors and religious orders with a basic three-step method of seeing, judging, and acting. The branches - best known outside Latin America - are professional theologians who follow developed and rigorous academic arguments in a threefold mediation of theology, namely socio-analytical, hermeneutical, and practical:

The socio-analytical mediation constitutes the material object of theology in its relation to the social sciences ("see"). The hermeneutical mediation constitutes the formal object of theology in its relation to Scripture and tradition ("judge"). The practical

6 See the discussion below where the first two forms of poverty are linked to two different forms of justice: distributive and cultural. 
mediation constitutes the concrete object of theology in its relation to pastoral and historical action ("act")

The metaphor of the tree already points out that the very methodological structure of liberation theology reflects and supports the preferential option for the poor. It is their experiences that inform liberation theology and provide pastoral and academic theologians with the core material for reflection in the light of Scripture and tradition. Liberation theology is therefore much more dialectical ${ }^{8}$ than analogical, and more historical-practical than merely analytical. This in turn implies both an epistemological and a methodological break with mainline, traditional (Western) theology

We can thus attempt a first reply to the question: Why this priority option for the poor? The methodological answer is: Because the lived realities of the poor impose themselves as the starting point of reflection on faith, and constitutes the "hinge" of the praxis ${ }^{10}$ process toward the liberation of the oppressed (see Sobrino 1984:27).

\subsection{The hermeneutic-exegetical argument}

If the methodological starting point is the experiences of the poor, a hermeneutical discussion of liberation theology must commence

$7 \quad$ See Boff and Boff (1984: 5-11; 49-55); Boff and Boff (1987:24ff) as well as the very structure of Clodovis Boff's Theology and praxis: epistemological foundations (1987). This latter book is for me the most illuminating and penetrating discussion of the concept of a praxis-oriented theology. Perceptive liberation theologians are obviously aware of the fact that the very "starting point" in the socio-political realities or "experience" presupposes some interpretation of those realities. "Hermeneutics" in the sense of "reflective interpretation" indeed underlies the whole liberation theological enterprise. See the discussion under 1.2 that follows below.

8 This term should not be interpreted in the Barthian sense of the word. Its origin lies in left-Hegelian and Marxist thought and refers to the development of history via dialectical movements of thesis, antithesis, and synthesis.

9 See how Gutierrez (1973: 3-15) attempts to link classical theologies to a liberation theology. For more detail, read Sobrino (1984:7-38) for an interesting and illuminating juxta-positioning of liberation and Western theologies.

10 The word "praxis" refers to the continuous movement from practice ("experience") to theory ("reflection") and back ("action"). For a detailed philosophical discussion, see chapter 1 of the unpublished thesis by Naude (1987). 
with the poor, ordinary people as primary readers of the Bible. The methodological option for the poor here turns into an epistemological and hermeneutical privilege: We learn the truth of the Bible through the eyes and life-histories of the poor. "No theoretical reading or quest for ideas is involved. The reading of the Bible as done by the poor is a matter of life and death, freedom and domination." (Gorgulho 1993:124). The primary context is the base communities and not the seminary or the university; and the "source" of biblical and exegetical reflection should be the readings accomplished by the poor.

The implications are that the Bible is not read as past history, but as a mirror of history occurring today. The chief aim is not an isolated interpretation of the Bible for the purpose of erudition, but an interpretation of life with the aid of the Bible which itself becomes a source of life. There is no search here for a "neutral" reading - the poor engage in a committed reading as they search their way out of oppression toward liberation (see Gorgulho 1993:124-125).

One of the most significant shifts in $20^{\text {th }}$ century hermeneutical studies occurred with the shift from the text to the reader as locus of meaning. (read Lategan and Vorster 1985). Meaning, it is argued, does not reside somewhere "in the autotelic text" where it is merely "retrieved" through historical, grammatical and structural analysis. Meaning is constructed by an interaction between text and reader. Without the reader the text is voiceless. In some extreme readeroriented views, the text is in fact constructed by the reader ${ }^{11}$. Thus, the important question is no longer: "What is read?", but rather "Who reads?" And the answer from Liberation Theology is straightforward: The poor and the marginalised are the preferred readers. Where a reader-oriented approach is coupled with a hermeneutics of suspicion $^{12}$ - specifically those from a Marxist or neo-Marxist origin - two crucial insights come to the fore:

11 For a concise discussion of hermeneutical approaches that emphasise the role of the reader, see Jonker and Lawrie (2005:112-128).

12 See Jonker and Lawrie (2005:167-228) for a general overview of "suspicion-hermeneutics" with a specific discussion by Lawrie of Marxist approaches on pages 189-199. 
First. In what has become known as materialist readings, the production of the Biblical text is itself viewed with "suspicion" based on who owns the means of production in the text-producing communities. Where a text originates or is over time edited by people in positions of political and economic power, they tend to show features of "status quo" texts. The opposite is naturally also true, so that the reader should seek out and rather follow the guidance of texts reflecting the views "from the underside" of society.

Second. In what has become known as social constructivist readings, the socio-economic position of the reader is itself of crucial importance. If the reader is the primary locus of meaning, such meaning will tend to reflect her/his social position. In short, rich and powerful people construct different meanings than the poor and the marginalized $^{13}$. And as many texts seem to address the needs of the latter, the epistemological privileged position now becomes one of hermeneutical privilege.

Based on these hermeneutical arguments, the exegetical key consequently shifts from notions like "justification by faith alone" (dominant in Reformed exegesis), the two kingdoms or the creative tension between law and gospel (arising from Lutheran work) to "liberation of the poor and the marginalized".

"From its point of departure in the anguish of the poor of this world, the whole biblical message emerges as a proclamation of liberation" (Boff and Boff 1984:26). Themes from the OT are liberation from Egypt, the special care for foreigners, widows and orphans in the law, social criticism against oppressing the poor in the prophets, and the admonitions against riches and care for the poor in the wisdom literature. In the NT much is made of Jesus' relation and ministry to sinners and marginalized people; the Lukan emphasis in Luke-Acts on the physically poor, the sharing of goods, and care for the widows in the earliest Christian communities. There is emphasis on the egalitarian elements in the Pauline corpus (like Galatians 3

13 See the many fruitful analyses of the insight by "ordinary readers" as set out by South African Old Testament scholar, Gerald West. See for example West $(1995 ;$ 1999). 
and Ephesians 2), and the obvious option for the poor in the book of James ${ }^{14}$.

Why this priority option for the poor? A second answer, highly simplified, is: "Because the Bible tells us so".

\subsection{Trinitarian argument}

This group of arguments is in many ways an extension of the hermeneutical views, though they represent the "doctrinal" dimension of the option for the poor.

\subsubsection{God}

If you live under wretched socio-economic or marginalized or oppressive conditions, and if you then read the Bible from the perspective of the poor, the very image of God that appears, is "the God of the oppressed". Gustavo Gutierrez (1993:239) calls this the theocentric basis of the option for the poor. And Jon Sobrino (1984:2, 33) writes: "In my opinion, God's manifestation, at least in Latin-America, is his scandalous and partisan love for the poor and his intention that the poor should receive life... The mediation of the absolutely Other takes the form of those who are really 'other': the oppressed".

Here hermeneutics becomes theology. In situations of entrenched economic injustice, God is on the side of the poor and is a different God from those who proclaim a prosperity gospel, perceiving God as guarantor for privileges and power. A theology that defends oppressive conditions, is a false theo-logy. "God" turns into idolatry; religion turns - as Marx rightly observed - into the opium of the people.

\subsubsection{Jesus Christ}

Liberation theologians have made rich contributions to our understanding of $\mathrm{Christ}^{15}$. One could point to a number of common emphases ${ }^{16}$ that reinforce the option for the poor:

14 As indicated above, the primary literature here is once again overwhelming. For an excellent summary and overview, read Pixley and Boff 1989, especially pp. 17-52 (The option for the poor in the Old Testament) and pp. 53-67 (The option for the poor in the New Testament). 
There is a definite return to the historical Jesus although not in the "archaelogical" or "historicist" sense of the word. Jesus is foremost seen as materially poor himself. His seeking out and healing of marginalised people demonstrate his own commitment to the poor. He is as "Word made flesh" the incarnation and revelation of God as the God of the poor. His ministry and preaching points to the coming kingdom of God with its radically inverted value system where the first will be last, and the last first.

Latin American liberation theology moves away from explaining the cross in terms of expiatory theories of reconciliation to a historical recovery of the cross as the world's condemnation of the poor and at the same time judgment against the sin of marginalization. There is an intrinsic link between cross and resurrection. The latter stands as the triumph of justice over injustice and as sign of hope for the crucified of history. Christology is not merely constructed by theories about Jesus or the post-Easter Lord, but by following Jesus in his solidarity with the poor. The only way to Christology, i.e. knowledge about Christ, is via discipleship, the following of Christ.

\subsubsection{Holy Spirit}

The Holy Spirit ${ }^{17}$ is the One who fills the prophets that speak against oppression; who prompts the songs of liberation sung by Miriam, Simeon and Mary; who creates the church as egalitarian prophet community (Ac 2); who groans with the whole creation, crying for justice and truth $(\mathrm{Rm} 8)$. Based on these biblical insights, the Spirit is the Divine force that works in history toward the radical transformation of society. The poor experience this Spirit as the Spirit that spurs them on to action; that delivers them from slavery and let them experience freedom; that leads them from oppressed

15 One immediately thinks of the seminal works by Jon Sobrino as published in English: Christology at the crossroads (1978), Jesus the liberator (1993) and Christ the liberator (2001).

16 I roughly follow the exposition by Julio Lois (1993), but add interpretations based on my reading of primary literature.

17 Comblin refers to the fact that pneumatology is quite under-developed in Latin-American theologies. The recent rise of popular Pentecostal movements in both the Protestant and Catholic churches serves as impulse to move beyond the patristic tradition of Latin theology (1993:462-463). 
silence to the freedom of the word, crying out "Abba Father"; that makes possible the experience of a new community; that brings amidst death - living waters of life (see Comblin 1993:464-471).

\subsubsection{Trinity}

Not only as separate Persons, but in community, the Trinity ${ }^{18}$ serves as example of self-donating love, non-hierarchical communion, and as basis for our critique of society. To create social embodiments of the Trinitarian communion, would require a new society that avoid the aberrations of both excessive individualism underlying capitalism and the collectivism of socialism. "The sort of society that would emerge from inspiration by the Trinitarian model would be one of fellowship, equality of opportunity, generosity in the space available for personal and group expression" (Boff 1998:151).

Why this preferential option for the poor? A third reply that would come from Liberation Theology is: Because this is how God as Trinitarian God has revealed God-self. As Boff puts it: "Oppressed Christians find an incomparable inspiration for the liberation struggle in the God of their faith" (1998:152, my emphasis).

\subsection{Ecclesiological argument}

The church is not so much a church for the poor as a poor church (see Sobrino 1985:84-124) 19. "Poverty is not a virtue unless it leads to the fellowship of the really poor. The poor church will therefore have to be understood as the church of the poor... (Moltmann $1981: 336)^{20}$.

18 Perhaps one could say that Leonardo Boff has done the most interesting work on Trinitarian theology from amongst the liberation theologians. See his Trinity and society (1988) and Holy Trinity, perfect community (2000) as examples of what has become known as "social trinitarianism".

19 Sobrino develops his ecclesiological views in this regard with strong reliance on Western theologians like Moltmann (see next quotation) and Hans Küng, but obviously adds his own perspectives from the Latin American situation.

20 This is a quotation from Moltmann's exposition of the marks of the church that, according to him, is holy in poverty. He argues that because Christ has been made poor "so that you might become rich" (2 Cor 8:9), the church is sanctified "wherever it participates in the lowliness, helplessness, poverty and suffering of Christ" (Moltmann 1981:355). 
Sobrino attempts to overcome three obstacles in understanding the church as a church of the poor: an idealist universalism, an ethical approach to the poor, and a segment approach to view the poor in the church as part of a wider sociological group.

First. The Second Vatican Council re-introduced the metaphor "people of God" for the church, and although this is clearly a move away from the strict hierarchical and mystical understandings of the church to a more democratic or participative notion, Sobrino maintains that a universalistic understanding of the people of God is still too vague. He argues that - like in the times of Isaiah and Jesus - the good news is for the poor as locus where God is found (Mt 25). The poor has therefore the sacramental value of being "a structural channel for the coming into being of the true Church" (1985:93). The church was historically borne of the poor and they remain the theological locus of being the church.

Second. A "church of the poor" is not an expression of the idea that the church has an ethical obligation to assist the poor whilst ignoring poverty. Yes, one can build a church for the poor, but that is not synonomous with a church of the poor, because the first assumes that "the Church is constituted in logical independence of the poor, and then goes on to ask what this Church must do for the poor. A Church of the poor, however, poses a strictly ecclesiological problem; it concerns the very being of the Church" (Sobrino 1985:92).

Third. "Church of the poor" does not simply imply that the poor is part of the church alongside others who are non-poor and who remain unaffected by the plight of the poor segment of the church. The Spirit of Jesus who is in the poor, recreates the entire church to become a church of the poor. The poor is the theological source of the entire church and being a church of the poor is the only way to seek and find God. Solidarity with the poor by being poor is an expression of the church's own kenosis (Sobrino 1985:95).

A fourth reply to the question why there is a preferential option for the poor, would be: The poor church expresses the essence of being church in the world today. 


\subsection{Theological conclusion and implications for understanding justice}

Much more could be said. But the profile drawn above is adequate for our purposes here: The preferential option for the poor is supported by and expressed in at least a four-dimensional theological construction:

1. A methodological starting-point in the experience of the poor which is then mediated via a praxis-process.

2. A hermeneutical choice to take the reading of ordinary people as point of departure; a "reading with suspicion" which particularly focuses on the social construction of both the text itself and the social location of the reader.

3. A doctrinal image of God, Jesus Christ, and the Spirit, as separate persons opting for the poor, and a triune community manifesting justice and charity.

4. A vision of the church as a poor church whose sanctification is bound up with solidarity with the poor.

The implications of this theological construct for our understanding of justice, are profound. For the sake of focus, let us look at the views expressed by Jon Sobrino in his discussion of the integral relationship between faith and justice.

He takes the kingdom of God as point of departure: Because God's reign embraces the totality of human relations and includes all of history, justice - as the concrete embodiment of love - must be understood in equally holistic terms. Justice concerns itself therefore not merely with inter-personal relations, but with structural relations as well. As humans are divided into "oppressor and oppressed", justice must concretely address the sin of structural economic disparity.

The partisan nature of this justice is expressed unreservedly: "Love in the form of justice has meant historically doing justice to the vast majority of the human race, namely, the poor... Historically, therefore, the concretisation of love as justice is a necessary and effective way of giving flesh to the great Christian truth that God is partial to the poor majority" (Sobrino 1984:77, my emphasis).

A more specific question is: Which forms of justice are at stake in the preferential option for the poor? The answer lies in a 
connection between two of the "poverty notions" referred to above: To address material poverty, distributive justice is at stake. To address socio-political poverty (marginalization), cultural justice is at stake.

Distributive justice $^{21}$ is a form of socio-economic justice that regulates the distribution of goods and services amongst the people of a specific society or amongst societies in a regional or global arrangement. The result of such a distribution will obviously depend on the meta-ethical notion of justice and the specific theory of justice adopted. Egalitarian understandings of justice will, for example, seek to spread benefits more equally than an entitlement notion of justice $^{22}$.

In the language of Latin American liberation theology, this is justice for the poor.

Cultural justice ${ }^{23}$ is a form of social justice that regulates the relationship amongst individuals from different cultural backgrounds or amongst whole cultural groups themselves. This may happen within or beyond the boundaries of nations-states, and on a global scale. Cultural justice aims to respect and protect distinct features of cultures, work against forms of marginalization based on factors like race or gender, and actively promote the celebration of the wide range of cultural and human diversity in a particular society or in the world as such.

In the language of Latin American liberation theology, this is justice for the marginalised.

The second part of this contribution is to establish whether and in what manner the same kind of preference emanates on completely different grounds from the philosophical theory of justice as presented by eminent political philosopher, John Rawls. In other

21 For a definition and wide-ranging discussion of different theories of distributive justice, read Roemer (1998).

22 This difference is, for example, illustrated in the debate between John Rawls (egalitarian view) and Robert Nozick (entitlement view).

23 This is a form of justice not as widely discussed in literature yet. I have found the essay by Kwenda (2003) very helpful in this regard. He argues that cultural justice is established when people are allowed unselfconscious living, i.e. live in acceptance and appreciation of own identity. For an analysis of the link between cultural justice, identity and globalization, read Naude (2005). 
words, what are the philosophical grounds - if any - for partisan justice?

\section{A PHILOSOPHICAL PERSPECTIVE ON "THE LEAST ADVANTAGED REPRESENTATIVE MAN" AND “BUR- DENED SOCIETIES”}

\subsection{Prioritarian distributive justice}

In his well-known $A$ theory of justice, Rawls (1971:60-90) develops a difference principle in which re-distributive policies allow for social and economic inequalities, but only if they result in compensating benefits for everyone, "and in particular for the least advantaged members of society" (Rawls 1971:14-15). The protection or improvement of the least advantaged therefore receives absolute priority in determining justice.

Rawls' defence of this priority is philosophically based on his choice against sum-utilitarianism and his preference for the contract tradition stemming form Hobbes, Locke, Rousseau and Kant. His methodological defence is based on his strategy to show that the difference principle (or maximum criterion) would be the rational choice for members of a future society who find themselves behind a veil of ignorance (1971:136-142) in an original contract position (1971:17-22). The (re)distribution of primary goods, identified by Rawls as "rights and liberties, opportunities and powers, income and wealth" $(1971: 62,92)$ must always satisfy the criterion of improving the worst off person's situation.

The measurement of this "worst off" person or what Rawls (1971:91) calls the identification of "the least advantaged representative man" may be determined by economists in terms of the Gini-index coupled to social welfare functions, or by the Lorenz curve which depicts the percentage of the total amount of income possessed by any given percentage of the poorest amongst the population (e.g. the poorest $20 \%$ of people share in $4 \%$ of total income $)^{24}$.

24 Frankfurt (1987) argues that this "priority" of those "worst off" should be given only to those below a certain threshold. One could apply his view to the current distinction between people living in poverty and those living in absolute poverty. 
In his later book, The law of peoples (1999), Rawls (1999:5455) extends his notion of "justice as fairness" to an international society composed of different peoples who have "distinctive institutions and languages, religions and cultures, as well as different histories". In an initial compact (the second original position) where representatives of the peoples meet behind a thick veil of ignorance (1999:32-33), eight principles of the "Law of Peoples" would hypothetically be agreed to (1999:37). This is not an agreement between free and equal individuals like in Rawls" "domestic version", but an agreement reached by distinct peoples via their rationally inclined representatives.

In what way could Rawls' "international" version of justice as fairness be interpreted as prioritarian as described above? Let us look at the principles of justice among free and democratic peoples as formulated by Rawls:

"1. Peoples are free and independent, and their freedom and independence are to be respected by other peoples.

2. Peoples are to observe treaties and undertakings.

3. Peoples are equal and are parties to the agreements that bind them.

4. Peoples are to observe a duty of non-intervention.

5. Peoples have the right of self-defence but no right to instigate war for reasons other than self-defence.

6. Peoples are to honor human rights.

7. Peoples are to observe certain specified restrictions in the conduct of war".

Whereas the first seven principles all presume equality and nonpartisanship, the addition of the last principle ${ }^{25}$ is significant:

8. "People(s) (sic) have a duty to assist other peoples living under unfavourable conditions that prevent their having a just or decent political and social regime" (Rawls 1999:37).

This is, according to my interpretation, the only law that moves Rawls' egalitarianism toward its special version of prioritarianism, namely "a duty" toward those "living under unfavourable

25 Rawls (1999:37, note 43) himself remarks: "This principle is especially controversial". 
conditions". Rawls (1999:106) refers to these as "burdened societies" 26 because they "lack the political and cultural traditions, the human capital and know-how, and often, the material and technological resources needed to be well-ordered".

Buchanan argues that Rawls does not adequately address the inequities built into the "global basic structure". The latter is seen as "a set of economic and political institutions that has profound and enduring effects on the distribution of burdens and benefits among peoples and individuals around the world" (Buchanan 2000:705). Rawls' laws therefore inadequately address issues of distributive justice in the current global order. Buchanan subsequently adds three further laws pertaining to global equality of opportunity, democratic participation in global institutions and a principle designed to limit inequalities of wealth among nations.

It may however be argued that a strong interpretation of the eighth principle does indeed imply re-distributive action: The "duty to assist" can hardly be practically conceived without some "transfer" or "sacrifice" from decent peoples living under more favourable conditions than those in the opposite situation ${ }^{27}$. Anton van Niekerk has convincingly argued that this duty is not merely a duty of charity, but indeed of justice. And that this law - even if construed as duty of charity - has no diminished moral force (Van Niekerk 2004:183).

The difference principle returns with the special and exclusive focus on "peoples living under unfavourable conditions". Here the earlier individuals who are worst off in a specific society are matched by peoples who are comparably worst off in the global system.

Some qualification is however required: Rawls does not accept a blanket global difference principle ${ }^{28}$. "Well-ordered peoples have a

26 A well-ordered and even rich society may become a burdened society through a natural disaster. Irrespective of the cause, Rawls argues that a rational view of reciprocity would agree to the principle that peoples have a duty to assist burdened societies.

27 The G-8 debt relief program or South Africa's contributions to the SADEC countries are cases in point.

28 Here Rawls (1999:115-119) differs from Charles Beitz whom he discusses. 
duty to assist burdened societies. It does not follow, however, that the only way, or the best way to carry out this duty of assistance is by following a principle of distributive justice to regulate economic and social inequalities among societies" (Rawls 1999:106, original emphasis).

The three guidelines ${ }^{29}$ for the duty to assist (1999:106-113) clarifies this: The aim of assistance is not primarily to reach greater equality in for example economic wealth, but to ensure that burdened societies are able "to establish reasonably just basic institutions for a free constitutional democratic society and to secure a social world that makes possible a worthwhile life for all its citizens" (Rawls 1999:107, see also page 5). The duty to assist is therefore a transitional duty linked to a specific target after which the duty is no longer in force as the former burdened society is now able or has become a member of the Society of well-ordered Peoples (see Rawls 1999:117-119).

This does not imply that no re-distributive justice or reducing of inequalities is at stake. It also does not exclude direct financial assistance (though Rawls is at pains to focus on political culture rather than economic aid $)^{30}$. The Society of Peoples may and will probably have members that are rich and poor in relative terms, but the latter will not be so poor (burdened) as to make the establishment and maintenance of a well-ordered society impossible.

Rawls explains that one of the preconditions for establishing just basic institutions, is meeting peoples' basic needs. "By basic

29 Simply put, these guidelines are: Assistance is not aimed at reduction in wealth inequalities per se, but in establishing just institutions; the establishment of a political culture and political virtues are crucial, and, despite being relatively poor, the inclusion of the burdened society in the Society of Peoples is the ultimate aim..

30 "What must be realized is that merely dispensing funds will not rectify basic political and social injustices (though money is often essential)". A focus on human rights and establishment of a democratic political culture is more important (1999:108-109). Rawls takes his cue inter alia from Sen's case studies of famine that shows the political and economic factors are mostly more important than "natural" factors such as droughts. This reinforces Rawls' view that assistance amongst peoples must carry political consequences, i.e. the creation of just institutions. 
needs I mean roughly those that must be met if citizens are to be in a position to take advantage of the rights, liberties, and opportunities of their society. These needs include economic means as well as institutional rights and freedoms" (Rawls 1999:38, note 47), and may (in my interpretation) be linked to the presence of adequate "primary goods" to secure a social world in which just political institutions can be built.

The duty to assist in the context of relations amongst peoples carries therefore - despite qualifications and restrictions - the same egalitarian consequences as the difference principle in domestic societies $^{31}$.

The principle, if applied to a-symmetrical power relations, implies the following:

In situations where for example indigenous people share membership of a domestic society with better off persons, and they happen to be in the worst off position (which is mostly the case), the difference principle would require that such people receive absolute priority in any re-distributive policy decision.

And in situations of global distributive decision-making, Rawls' principle of assistance would require that, whatever the outcome of such a decision, it should not diminish the fulfilment of basic needs of the poorest people to the margin where citizens are unable to build just institutions or take advantage of available rights and opportunities. The rational and just thing to do in the (second) original position is to maximize the minimum where the latter is linked to the potential to build a well-ordered Society of Peoples, because the people you represent in the second original position might find themselves to be a burdened society.

\subsection{Prioritarian cultural justice}

The link between justice as fairness and culture is addressed by Rawls in a number of ways in A theory of justice (see 1971:101, 325, $331,525)$. The most important aspect for our argument here is Rawls insistence that "perhaps the most important primary good is that of self-respect". It is worth quoting him in full:

31 Rawls (1999:14, note 5) remarks that among various interpretations of liberalism, "justice as fairness is the most egalitarian". 
"We may define self-respect as having two aspects. Fist of all... it includes a person's sense of his own value, his secure conviction that his conception of the good, his plan of life, is worth carrying out. And second, self-respect implies a confidence in one's ability, as far as it is within one's power, to fulfil one's intentions. When we feel that our plans are of little value, we cannot pursue them with pleasure... Nor plagued by failure and self-doubt can we continue our endeavours. It is clear then why self-respect is a primary good... Therefore the parties in the original position would wish to avoid at almost any cost the social conditions that undermine selfrespect” (Rawls 1971:440, my emphasis).

That Rawls (1971:525ff) is - even in this domestic version not merely speaking in individualist terms, is apparent from his discussion of historical identity and social unions as the mark of just and well-ordered societies. It takes very little insight to see in Rawls' quotation the intrinsic link between justice and what was referred to as "culture". Being self-conscious in a negative sense, always being one step or sentence or technological innovation behind, undermines self-respect and leads to cultural diffidence. This is a disposition that causes indigenous people either to be ashamed of their culture or to simply ignore it as irrelevant in the world beyond their own confines. It is the internalised conviction that "the own" (language, music, race, gender, art) is worse than "the dominant other" and of no significance in greater society.

One can therefore read Rawls to say cultural justice, the social condition that strengthen self-respect, would be promoted at all cost by the parties in the original position. You would do that because you could theoretically belong to an indigenous people or minority race/gender group, vulnerable to the homogenisation and assimilation forces of dominant national and Anglophone global cultures.

Rawls' The Law of Peoples is also specifically fruitful in promoting issues underlying cultural justice.

His choice of "peoples" in stead of "nations" or "states" is significant as he argues that peoples and not states are the actors in the Society of Peoples. Liberal peoples have three basic features which are linked to institutions, culture and morality (Rawls 1999:23-25). "The term 'peoples', then, is meant to emphasize these singular features of peoples as distinct from states...". He further 
places particular emphasis on the wide range of distinctive features amongst different peoples: They have "distinctive institutions and languages, religions and cultures, as well as their different histories" (1999:54-55); they have distinct values, traditions and ideas of justice, and are united by "common sympathies" (Rawls 1999:24, 25).

Other than states, peoples perceive their interests inter alia in terms of honour ${ }^{32}$. Echoing the notion of self-respect in domestic societies, Rawls explains: "This interest is a people's proper selfrespect of themselves as a people, resting on their common awareness of their trials during their history and of their culture with its accomplishments". This interest "shows itself in a people's insisting on receiving from other people a proper respect and recognition of their equality" (1999:34-35, my emphasis).

The priority view underlying the eighth principle, is equally applicable to cultural issues. The "duty to assist" has a specific focus, namely to alleviate "unfavourable conditions". Which are these conditions? Those that prevent "a just or decent political and social regime" wherein this proper respect and recognition of cultural equality are absent. Cultural injustice exactly arises where legitimate differences are denied political-legal protection, and where social conditions prevent people from "unselfconscious living" (see Kwenda 2003:73).

Rawls' emphasis on the "distinctiveness" of peoples has earned him the criticism of cultural relativism (see Cohen 2004:117). He however based his views on the strong conviction that tolerance is a basic principle underlying international cooperation. There must be respect for peoples' freedom and independence (first principle); duty of non-intervention (principle 4), and the honouring of human rights (principle 6) that would - in the context of this paper - include the freedom to live under conditions of cultural justice in both national and global contexts. For Rawls (1999:64-67) this even includes the freedom to choose against ordering society according to liberal principles, whilst remaining "decent societies".

32 See Rawls extension of what Rousseau calls amour-propre in footnote 38 on page 34, as well as his reliance on the contract notion of Rousseau throughout his work. See Rawls $(1999: 7,13)$ as example. 


\subsection{Philosophical conclusion}

It has been argued in section one that the preferential option for the poor is the basis of Latin American liberation theologies and has serious implications for our understanding of both distributive and cultural justice. Section two undertakes a reading of Rawls to establish whether these forms of justice are present in their partisan form as is the case in liberation theologies. We have seen that a Rawlsian proposal for an egalitiarian and prioritarian conception of justice requires the absolute priority of both the least advantaged representative individual in a domestic society, and the meeting of basic needs of those peoples living under the most unfavourable conditions in a global society.

It is now opportune to draw out some of the implications of this concurrence between theological and philosophical views.

\section{IMPLICATIONS OF PARTISAN JUSTICE FOR LOCAL AND GLOBAL ETHICS}

What are the implications of the theological and philosophical arguments for these specific forms of partisan justice? Following some of Bedford-Strohm's (1993:306-313) points, the following are listed as conclusion to this paper.

First. The material synergy between a global ecumenical consensus and one of the most plausible and legitimate political philosophies of the $20^{\text {th }}$ century, gives social and political credence to the notion of a preferential option for the poor. This synergy is no small achievement as it witnesses to the influence of theological ethics (broadly speaking) on political theory; but in turn provides evidence of secular arguments for and confirmation of a primary theological notion. The option for the poor is obviously open for different interpretations, and some may even speak up against it; but the fact of the matter is: This option can no longer be ignored. Not by Christians who read the Bible or take the voice of the church seriously, and who could reject the notion as mere "political talk". Nor can this option be ignored by rational secularists who would under normal circumstance be prone to reject the idea as merely "church talk". Partisan justice is firmly on the international political and economic agenda - and it has legitimacy.

Second. One of the strongest criticisms against the option for the poor has been that is strong prophetic talk, but unless given more 
precise content on principles of (re)distribution, would serve only a narrow rhetorical function. Poverty is obviously a relative concept: the poor in one society (Belgium) may be rich when compared with another (Somalia). Liberation theologians particularly attempted to define "the poor" in material, socio-cultural and spiritual terms (see Pixley and Boff 1989:166). It is possible today to extend definitions of the poor to our global society and work with adjusted empirical data of the baseline (expressed in for example dollar terms) under which people will be considered poor. Theological and church literature did not put forward a practical measure to guide redistributive policies that will ensure the option for the poor and reduce inequalities. The value that Rawls add is to develop a universal criterium which formally addresses any situation, no matter how and where this baseline is set: Inequalities are allowed only insofar as they benefit the least advantaged representative person in a particular society or the least advantage peoples in a global setting.

Third. The option for the poor assists us to understand the crucial importance of another form of justice, namely participative justice. Bedford-Strohm (1993:169) makes the astute observation that both material and socio-cultural poverty find their origin in "fehlende Teilhabe". People are materially poor because of a lack of participation in the (in)formal economy - that is one of the most urgent issues in discussions of global economic justice today. And people are socio-culturally poor because they are excluded and marginalised from full participation in society based on race or culture or gender or something else. Participative justice breaks through the paternalism and ultimate failure of development aid where "things are done for the poor", and establishes a crucial link clearly demonstrated by Rawls and insisted upon by liberation theologians - between democracy and egalitarian, well-ordered societies. Distributive and cultural justice in their focussed form as partisan justice can only be realised via extending participative justice.

Fourth. Both theological and philosophical proponents of the option for the poor emphasize that - contrary to popular perception this option is not exclusive, but exactly inclusive. God's solidarity with the poor - so clear in the biblical trajectories - is a pastoral and not a salvation-historical notion. It requires a priority not an exclusion. That Jesus sides with the poor and was poor himself, does 
in no way detract from the universal significance of his cross and resurrection. Care for the poor, the widows and the orphans is a sign of a just, covenant community in which all are involved. Showing no preferential treatment to the rich, serves the whole faith community, and is the mark of a sincere religion before God, teaches James. Rawls has similar intentions: The choices made in the original position according to the maximum principle is exactly designed to contribute to a stable, well-ordered society, locally as well as globally. It is today accepted that a super-rich North and dismally poor South is not in the long run sustainable. Nor is an extreme gap between rich and poor within one nation contributing to social stability, because the latter is a basic requirement for all to achieve fulfilment in life. In short: whether you argue from a deontological or instrumental ethical perspective, the option for the poor is an inclusive strategy worthy of universal support.

Fifth. It must be evident that the option for the poor is a critical notion. It is not just another interesting theory amongst other. It has the ability to judge current socio-economic policies and outcomes. In terms of Gustafson's stratification of moral language, the option for the poor can make the transition from prophetic to policy statements. There is not room here to develop a detailed example, but it has been suggested ${ }^{33}$ that the core indicator of public policy should not be economic GDP-growth, but whether the past year has led to an improvement in the position of the least advantaged persons/groups in society. An annual "poverty report" should be the primary driving factor behind public policy as well as the basis for a policy or cabinet score-card at the end of each year.

It does not take a lot of imagination to see the radical impact on public policies of the preferential option for the poor as expressed in the notion of partisan justice. Some empirical case studies are needed to test partisan justice as a form of applied ethics.

\section{Consulted literature}

Bedford-Strohm, H 1993. Vorrang für die Armen. Auf dem Weg zu einer theologischen Theorie der Gerechtigkeit. Gütersloh: Chr. Kaiser Verlag.

Boff, C 1983. Theology and praxis: epistemological foundations. New York: Orbis.

Boff, L 1988. Trinity and society. New York: Orbis. 
Boff, L \& Boff, C 1984. Salvation and liberation. New York: Orbis.

-, 1987. Introducing liberation theology. New York: Orbis.

Buchanan, A 2000. Rawls's Law of Peoples: Rules for a vanished Westphalian world. Ethics 110 (4): 697-721.

Cohen, J 2004. The importance of philosophy: Reflections on John Rawls. South African Journal of Philosophy 23(2), 113-119.

Ellacuria, I and Sobrino J (eds.) 1993. Mysterium Liberationis. Fundamental concepts of liberation theology. New York: Orbis.

Frankfurt, H G 1987. Equality as a moral ideal. Ethics 98(1), 21-43.

Gorgulho, da Silva G 1993. Biblical hermeneutics, in Ellacuria and Sobrino, 123-149.

Gutierrez, G 1973. A theology of liberation. London: SCM.

-, 1993. Option for the poor, in Ellacuria and Sobrino, 235-250.

Kwenda, C V 2003. Cultural justice: the pathway to reconciliation and social cohesion. In Chidester, David, Dexter, Philip and Wilmot, James. 2003. What hold us together. Social cohesion in South Africa. Cape Town: HSRC Press, 67-80.

Lategan, B C and Vorster, W S 1985. Text and reality. Aspects of reference in biblical texts. Atlanta: Scholars Press.

Lois, J 1993. Christology in the Theology of Liberation, in Ellacuria and Sobrino, 168-193.

Maimela, S and König, A 2001. Initiation into theology. Pretoria: Van Schaik.

Moltmann, J 1981. The church in the power of the Spirit. A contribution to messianic ecclesiology. London: SCM.

Naude, P J 1987. Ortopraksie as metodologiese prinsipe in die sistematiese teologie. Ongepubliseeerde DTh-tesis. Stellenbosch: Universiteit van Stellenbosch.

-, 2005. The ethical challenge of identity formation and cultural justice in a globalizing world. Scriptura 89, 536-549.

Oliveros, Roberto 1993. History of the Theology of Liberation, in Ellacuria and Sobrino, 3-32.

Pixley, G V and Boff, C 1989. The Bible, the church and the poor. New York: Orbis.

Rawls, J 1971. A theory of justice. Oxford: OUP.

-, 1999. The law of peoples. Cambridge, Massuchusetts: Harvard University Press.

Roemer. J E 1998. Theories of distributive justice. Cambridge, Massuchusetts: Harvard University Press.

Sobrino, J 1984. The true church and the poor. New York: Orbis.

Sen, A 1988. On ethics and economics. Oxford: Blackwell. 
Van Niekerk, A A 2004. Principles of global distributive justice: moving beyond Rawls and Buchanan. South African Journal of Philosophy 23(2), 171-194.

West, G 1995. Biblical hermeneutics of liberation: Modes of reading the Bible in the South African context. New York: Orbis.

-, 1999. Academy of the poor: towards a dialogical reading of the Bible. Sheffield: Sheffield Academic Press.

World Council of Churches 1991. Confessing the one faith. An ecumenical explication of the Apostolic faith as it is confessed in the NiceneConstantinopolitan Creed (381). Geneva: WCC. 